Kredo 4 (2021)
KREDO: Jurnal Ilmiah Bahasa dan Sastra
Terakreditasi Sinta 4 berdasarkan Keputusan Direktorat
Jenderal Penguatan Riset dan Pengembangan,
Kementerian Riset, Teknologi dan Pendidikan Tinggi
Republik Indonesia
Nomor: 23/E/KPT/2019. 08 Agustus 2019
https://jurnal.umk.ac.id/index.php/kredo/index

\title{
NILAI-NILAI BUDAYA JAWA DALAM UNGKAPAN JAWA YANG BERLATAR RUMAH TANGGA PADA NOVEL CANTING KARYA FISSILMI HAMIDA
}

\author{
Sri Suharti \\ sri.rsh@bsi.ac.id
}

Universitas Bina Sarana Informatika, Indonesia

Info Artikel
Sejarah Artikel
Diterima
22 Maret 2021
Disetujui
17 April 2021
Dipublikasikan
19 April 2021
Keywords
Javanese Cultural Values
Javanese Expressions
Household
Harmonious
Novels

Kata Kunci

Nilai Budaya Jawa Ungkapan Jawa Rumah Tangga Harmonis Novel

\begin{abstract}
: :

A harmonious household is the dream for every people. A lot of efforts can be done to build a harmonious household. One of the way for building the harmonious household, is by setting a certain value system as the basis of a household. That value system could be sourced from legal, religion, social, and culture. There is no doubt that Javanese culture is the source of the values basis for a household. These values could be expressed by an oral tradition form called Javanese expressions. Javanese expressions are a expression form of Javanese ideas through the beautiful and high valuable words which containing the moral values. That value could be as a life guidance for peoples and community in various purposes, including in household life as a life after married. This study reveals Javanese cultural values in Javanese expressions

: within a household life background in the novel entitled Canting by Fissilmi Hamida. This study conducted by a sociology of literature approach with descriptive analysis method. The results of this study found that there are five Javanese cultural values contained in Javanese expressions within a household background in the novel entitled Canting by Fissilmi Hamida, namely belief value (firmness), patience value, achievement value (hopes and goals), and harmony value.
\end{abstract}

Abstrak

Rumah tangga harmonis adalah dambaan setiap orang. Banyak upaya yang dapat dilakukan untuk menciptakan rumah tangga harmonis. Salah satunya dengan menjadikan sistem nilai tertentu sebagai landasan berumah tangga. Sistem nilai tersebut bisa bersumber dari hukum, agama, sosial, maupun budaya. Budaya Jawa sebagai sumber tata nilai sebagai landasan berumah tangga tidak diragukan lagi keberadaannya. Tata nillai tersebut dituangkan dalam bentuk tradisi lisan yang disebut dengan ungkapan Jawa. Ungkapan Jawa merupakan bentuk ekspresi ide gagasan Jawa melalui kata-kata yang bernilai indah dan tinggi dan mengandung nilai-nilai moral yang dapat dijadikan sebagai pedoman hidup bagi masyarakat dalam beraneka tujuan, termasuk dalam menjalani berumah tangga. Penelitian ini mengungkap nilai-nilai budaya Jawa dalam ungkapan-ungkapan Jawa berlatar rumah tangga dalam novel Canting karya Fissilmi Hamida. Penelitian ini menggunakan pendekatan sosiologi sastra dengan metode analisis deskriptif. Hasil penelitian menunjukkan ada empat nilai budaya Jawa yang terdapat dalam ungkapan-ungkapan Jawa berlatar rumah tangga dalam novel karya Fissilmi Hamida yaitu nilai keyakinan (keteguhan), nilai kesabaran, nilai pencapaian (harapan dan cita-cita), nilai keselarasan. 


\begin{tabular}{|c|c|c|}
\hline & $\begin{array}{c}\text { Kredo } 4(2021) \\
\text { KREDO: Jurnal Ilmiah Bahasa dan Sastra } \\
\text { Terakreditasi Sinta } 4 \text { berdasarkan Keputusan Direktorat } \\
\text { Jenderal Penguatan Riset dan Pengembangan, } \\
\text { Kementerian Riset, Teknologi dan Pendidikan Tinggi } \\
\text { Republik Indonesia } \\
\text { Nomor: 23/E/KPT/2019. 08 Agustus 2019 } \\
\text { https://jurnal.umk.ac.id/index.php/kredo/index }\end{array}$ & 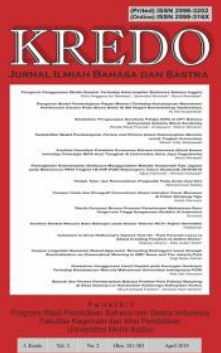 \\
\hline
\end{tabular}

\section{PENDAHULUAN}

UU No. 1 Tahun 1974 menyebutkan bahwa perkawinan adalah ikatan lahir batin antara seorang pria dan seorang wanita sebagai suami isteri dengan tujuan membentuk keluarga atau rumah tangga yang bahagia dan kekal berdasarkan Ketuhanan Yang Maha Esa. Dari definisi tersebut diketahui bahwa kebahagiaan, kelanggengan, dan keharmonisan merupakan tujuan yang sangat didambakan oleh setiap pasangan yang membina rumah tangga. Akan tetapi, pada faktanya untuk mewujudkan impian tersebut diperlukan usaha yang tidak mudah karena membina rumah tangga harmonis memerlukan proses penyesuaian yang sangat panjang dan kompleks.

Dalam rumah tangga, dua individu yang memiliki latar belakang sosial, budaya, dan kepribadian yang berbeda disatukan. Perbedaan-perbedaan tersebut diharapkan tidak menjadi kendala dalam meraih keharmonisan. Justru sebaliknya, dengan adanya perbedaan diharapkan saling mengisi dan terus-menerus melakukan penyesuaian sehingga akan tercipta keharmonisan. Akan tetapi, dalam kehidupan nyata, perbedaan-perbedaan tersebut sering menyebabkan konflik, perselisihan, dan kekerasan dalam rumah tangga. Banyak pula pasangan suami istri yang tidak mampu mempertahankan rumah tangga dan memilih mengakhirinya dengan perceraian.

Pada era globalisasi dewasa ini, yang mana budaya kita telah didominasi oleh budaya Barat, khususnya konsumerisme, hedonisme, dan materialisme sehingga membentuk rumah tangga harmonis memiliki tantangan tersendiri. Mustofa (2008) mengatakan bahwa budaya global sangat menjunjung tinggi kebebasan pribadi untuk berekspresi sehingga bertentangan dengan budaya kita yang menjunjung tinggi nilai-nilai moral. Budaya global ini telah menyelusup dalam segala bidang kehidupan melalui teknologi informasi dan komunikasi yang semakin canggih dan telah menggerus nilai-nilai budaya lokal yang ada, termasuk nilai-nilai dalam berumah tangga. Dampaknya adalah terjadi perubahan nilai, pola pikir, dan gaya hidup pada masyarakat sebagai individu yang berperan dalam rumah tangga.

Ajrin (2017) mengatakan bahwa rumah tangga harmonis akan tercapai jika masing-masing pihak saling dan memahami hak, kewajiban, serta peran kedudukannya secara sadar. Namun, pada faktanya budaya global telah menyebabkan perubahan konsentrasi keluarga. Banyak pasangan suami istri yang hanya terfokus untuk mencari kesenangan dan kenikmatan dalam kehidupan perkawinan, tanpa berpikir peran dan tanggung jawab (Mustofa, 2008). Akibatnya apabila kehidupan 


\begin{tabular}{|c|c|c|} 
Kredo 4 (2021) \\
KREDO: Jurnal Ilmiah Bahasa dan Sastra \\
Terakreditasi Sinta 4 berdasarkan Keputusan Direktorat \\
Jenderal Penguatan Riset dan Pengembangan, \\
Kementerian Riset, Teknologi dan Pendidikan Tinggi \\
Republik Indonesia \\
Nomor: 23/E/KPT/2019. 08 Agustus 2019 \\
https://jurnal.umk.ac.id/index.php/kredo/index
\end{tabular}

perkawinan itu tidak dapat lagi memberikan lagi apa mereka cari, maka mereka akan memilih jalan mereka sendiri-sendiri. Hal ini menimbulkan erosi kesakralan lembaga perkawinan sehingga perceraian sebagai konsekuensinya menjadi suatu hal yang biasa.

Meskipun tidak mudah, membina rumah tangga harmonis adalah suatu yang harus selalu diperjuangkan. Salah satu upaya yang dapat dilakukan adalah dengan menjadikan suatu tatanan atau sistem nilai tertentu sebagai dasar sekaligus pedoman bagi pasangan yang hidup bersama (Pitoyo, 2009). Dengan sistem nilai tertentu sebagai landasan berumah tangga, pasangan suami istri akan saling menyadari dan saling mengerti peran dan kedudukannya sehingga rumah tangga yang dibangun dan dibina mampu berdiri tegak dan mengayomi tiap-tiap individu yang bernaung di dalamnya. Sistem nilai tersebut bisa berasal dari berbagai sumber, bisa dari agama, hukum, maupun budaya.

Budaya Jawa sebagai sumber nilai landasan rumah tangga harmonis tidak perlu diragukan lagi keberadaannya. Budaya Jawa yang adiluhung telah memberikan perhatian yang sangat besar terhadap keharmonisan rumah tangga. Hal ini dibuktikan dengan adanya upacara adat perkawinan Jawa yang terkenal dengan nama wiwahan yang memuat banyak sekali simbol- simbol tentang harapan dan nasihat akan rumah tangga harmonis (Jazeri, 2020). Selain upacara perkawinan, ajaranajaran tentang membangun rumah tangga harmonis juga dituangkan dalam berbagai karya sastra Jawa berupa karya sastra piwulang. Karya sastra piwulang adalah genre sastra yang berisi ajaran, baik tentang perilaku di masyarakat atau ajaran mengenai cara menggapai kesempurnaan hidup. Biasanya sastra piwulang digubah tokoh yang memiliki wibawa besar di dalam tradisi sastra dan mitologi Jawa. Di antara karya wulang tersebut adalah Serat Candrarini, Serat Darmawasita, Serat Wulang Putri, dan sebagainya.

Serat Candrarini mengajarkan para wanita tentang bagaimana membangun dan mempertahankan rumah tangga harmonis (Pikatan, 2012 dan Puspitasari, 2016). Di antaranya adalah pandai merawat diri, berbakti pada suami dan mertua dengan sebaikbaiknya, pandai menyimpan rahasia rumah tangga, pandai mengatur perekonomian keluarga, sekaligus mampu menjadi pendidik dalam keluarga. Dalam karya sastra ini, disebutkan bahwa perceraian merupakan hal tercela bagi wanita Jawa (Wahjono, 2004). Oleh karena itu, perkawinan harus dipertahankan dengan berperilaku sesuai ajaran- ajaran tersebut.

Ajaran rumah tangga harmonis juga terdapat dalam Serat Darmawasita 


\begin{tabular}{|c|c|c|} 
Kredo 4 (2021) \\
KREDO: Jurnal Ilmiah Bahasa dan Sastra \\
Terakreditasi Sinta 4 berdasarkan Keputusan Direktorat \\
Jenderal Penguatan Riset dan Pengembangan, \\
Kementerian Riset, Teknologi dan Pendidikan Tinggi \\
Republik Indonesia \\
Nomor: 23/E/KPT/2019. 08 Agustus 2019 \\
https://jurnal.umk.ac.id/index.php/kredo/index
\end{tabular}

karya Mangkunegoro IV. Karya sastra ini berisi nasehat kepada putra-putrinya dalam mengarungi rumah tangga agar kokoh, harmonis, dan lestari (Pitoyo, 2009). Meskipun secara tersurat nasihat itu ditujukan kepada putra-putri raja, pada hakikatnya nasihat atau ajaran tersebut dapat dipakai siapa saja. Ajaran moral berumah tangga yang dipaparkan dalam Serat Darmawasita tidak hanya memberi pedoman moral bagi suami, tetapi juga istri. Suami sebagai pemimpin rumah tangga merupakan the owner yang paling bertanggung jawab terutama dalam hal menegakkan perekonomian keluarga. Adapun pedoman moral bagi isteri adalah seorang isteri harus menjadi pasangan yang patuh, taat, dan setia pada suami. Sebagai pemangku rumah tangga, istri harus mampu mengayomi seluruh anggota keluarga. Dalam rumah tangga, etika berkomunikasi juga harus senantiasa dijaga, agar pergaulan hidup, lebih khusus lagi pergaulan suami isteri dapat berjalan dengan kokoh, harmonis, dan lestari.

Serat Wulang Reh Putri juga mengandung ajaran-ajaran membangun rumah tangga harmonis bagi para istri. Ajaran dalam teks tersebut mengutamakan kepatuhan istri kepada suami. Seorang suami merupakan panutan bagi seorang perempuan sehingga segala perintah dan permintaannya harus dituruti. Seorang istri juga harus menunjukkan rasa sayang dan hormat kepada suaminya. Serat Wulang Reh Putri juga mengajarkan para perempuan agar menghormati lembaga perkawinan. Seorang perempuan dilarang keras mendekati pergaulan bebas ataupun perselingkuhan.

Selain dituangkan dalam bentuk simbol-simbol upacara perkawinan dan karya sastra, ajaran membangun rumah tangga harmonis juga termuat dalam tradisi lisan. Tradisi lisan itu berupa ungkapan-ungkapan Jawa. Ungkapan dalam bahasa Jawa bermacam-macam jenisnya, antara lain bebasan, paribasan dan saloka.

Sundari (2008) mengemukakan ada beberapa ungkapan yang memuat ajaran membangun rumah tangga harmonis. Ungkapan-ungkapan tersebut antara lain rukun agawe santosa yang bermakna bahwa bersatu akan membuat kekuatan, artinya memberikan pengertian yang mendasar bagi pasangan suami istri bahwa kerukunan akan menjadikan keluarga makin berbahagia, sentosa, dan sejahtera. Sabar darana awatak sagara memiliki makna yaitu bersabarlah seperti watak air laut yang selalu siap dengan berbagai keadaan. Makna yang diharapkan yaitu siap menghadapi berbagai tantangan yang akan dilalui. Ing ngarsa sung tuladha memiliki makna dan pesan yaitu kedua mempelai siap menjadi contoh bagi anak dan keturunannya. Tut wuri handayani memiliki makna dan 


\begin{tabular}{|c|c|c|} 
Kredo 4 (2021) \\
KREDO: Jurnal Ilmiah Bahasa dan Sastra \\
Terakreditasi Sinta 4 berdasarkan Keputusan Direktorat \\
Jenderal Penguatan Riset dan Pengembangan, \\
Kementerian Riset, Teknologi dan Pendidikan Tinggi \\
Republik Indonesia \\
Nomor: 23/E/KPT/2019. 08 Agustus 2019 \\
https://jurnal.umk.ac.id/index.php/kredo/index
\end{tabular}

pesan yaitu agar kedua mempelai akan menjadi sumber ide yang baik bagi keluarganya, yaitu berbuat yang baik agar tercapai cita-citanya. Adapun tata, titi, tentrem karta raharja memiliki makna pesan yaitu kedua mempelai supaya bertindak yang baik dan teratur, juga tetiti dan berhati-hati dalam tindakan sehingga tercapai kehidupan yang tenteram dan damai. Tentunya masih banyak sekali ungkapanungkapan bahasa Jawa yang mengandung ajaran-ajaran bagaimana membina rumah tangga harmonis.

Namun, yang sangat disayangkan, pada masa sekarang ungkapanungkapan Jawa tersebut hanya dikenal dan dipahami oleh segelintir masyarakat. Sebagian besar masyarakat, lebih memilih mengagungkan budaya asing dan meninggalkan nilai-nilai budayanya sendiri. Ada istilah "wong jawa wis ilang jawane". Suatu ungkapan yang ditujukan kepada masyarakat Jawa yang meninggalkan nilai-nilai luhur budaya Jawa.

Di tengah masyarakat yang mulai kehilangan orientasi, novel Canting karya Fissilmi Hamida hadir memberikan angin segar khususnya pada generasi muda. Novel Canting memberikan inpirasi bagaimana membangun rumah tangga harmonis melalui ungkapan-ungkapan Jawa yang bijak. Penelitian ini bermaksud mengungkap nilai-nilai budaya yang terkandung dalam ungkapan-ungkapan

555 | Jurnal Kredo

Vol. 4 No. 22021
Jawa berlatar rumah tangga pada novel Canting karya Fissilmi Hamida. Penelitian ini diharapkan dapat membantu masyarakat dalam memahami nilai-nilai budaya Jawa guna mempertahankan dan membangun rumah tangga yang harmonis dan bahagia.

\section{KAJIAN TEORI}

\section{Rumah Tangga Harmonis}

Rumah tangga adalah suatu kumpulan dari masyarakat terkecil yang terdiri dari pasangan suami istri, anakanak, mertua, dan sebagainya. Terwujudnya rumah tangga yang sah setelah akad nikah atau perkawinan, sesuai dengan ajaran agama dan undangundang (Bakry, 1996). Dari pengertian tersebut, disimpulkan bahwa rumah tangga merupakan suatu unit masyarakat terkecil yang terbentuk karena adanya ikatan perkawinan yang sah dan diakui oleh agama maupun negara. Dengan adanya ikatan perkawinan, maka pasangan suami istri merupakan kunci utama bagi terbentuknya rumah tangga.

Harmonis berasal dari kata harmoni yang berarti keserasian atau keselarasan. Harmonis juga berarti seiya sekata. Rumah tangga harmonis berarti keadaan rumah tangga selalu berada dalam keserasian dan keselarasan (KBBI Kemendikbud) .Dengan kata lain, rumah tangga harmonis berarti keadaan rumah 


\begin{tabular}{|c|c|c|} 
Kredo 4 (2021) \\
KREDO: Jurnal Ilmiah Bahasa dan Sastra \\
Terakreditasi Sinta 4 berdasarkan Keputusan Direktorat \\
Jenderal Penguatan Riset dan Pengembangan, \\
Kementerian Riset, Teknologi dan Pendidikan Tinggi \\
Republik Indonesia \\
Nomor: 23/E/KPT/2019. 08 Agustus 2019 \\
https://jurnal.umk.ac.id/index.php/kredo/index
\end{tabular}

tangga yang serasi, selaras, rukun, dan seiya sekata.

Menurut Saiin (2018), rumah tangga harmonis merupakan keadaan tercapainya kebahagiaan dan kebersamaan setiap anggota dalam suatu rumah tangga dan sedikit sekali terjadi konflik, sehingga para anggota merasa tentram dan dapat menjalankan perannya masing-masing dengan baik. Dari pengertian ini, rumah tangga harmonis ditandai oleh terwujudnya keinginan, cita-cita, dan harapan-harapan setiap anggota rumah tangga. Rumah tangga harmonis juga ditandai oleh minimnya konflik, percekcokan, ataupun pertengkaran. Rumah tangga harmonis berarti seluruh anggota rumah tangga merasa hidup tentram dan dapat menjalankan perannya masing-masing dengan baik.

\section{Nilai-Nilai Budaya Jawa}

Nilai adalah sesuatu yang dipandang berharga oleh individu maupun kelompok yang dapat dijadikan sebagai pedoman dalam bertindak maupun sebagai penentu arah hidup (Oktaviani, 2010). Nilai tumbuh melalui sarana kebudayaan yang dihayati sebagai jagat makna hidup dan diwacanakan serta dihayati melalui jagat simbol.

Nilai budaya Jawa dapat diartikan sebagai konsep-konsep mengenai apa yang hidup di alam pikiran sebagian besar masyarakat Jawa yang dianggap berharga dan penting dalam hidup sehingga dapat berfungsi sebagai pedoman hidup bagi masyarakat Jawa (Koentjaraningrat, 1984 dan Rachim \& Nashori, 2007). Sebagai pedoman hidup, nilai-nilai budaya Jawa memberi arah dan orientasi kepada kehidupan masyarakat Jawa.

Nilai-nilai budaya Jawa memiliki unsur-unsur yang membangun sisi manusiawi yaitu menyelaraskan manusia. Dalam menyelaraskan manusia, nilai-nilai budaya Jawa berfungsi mengarahkan dan membimbing perilaku manusia. Hal ini berarti nilai-nilai budaya Jawa berfungsi untuk mengupayakan keteraturan dan kesempurnaan dalam kehidupan masyarakat Jawa agar sistematis dan seimbang.

\section{Ungkapan Jawa}

Menurut KBBI, ungkapan adalah kelompok kata atau gabungan kata yang menyatakan makna khusus (KBBI Kemendikbud). Ungkapan menggunakan kata-kata yang khas untuk melahirkan kata kias.

Menurut Sundari (2008), ungkapan merupakan media penyampai pesan yang berwujud ungkapan tutur lisan dan memiliki bentuk berupa kata, frasa, maupun kalimat. Ungkapan berfungsi sebagai media untuk informasi berupa nasihat, tuturan, petuah, dan saran bagi yang diharapkan dapat bermanfaat bagi pihak-pihak yang berkepentingan. 


Kredo 4 (2021)
KREDO: Jurnal Ilmiah Bahasa dan Sastra
Terakreditasi Sinta 4 berdasarkan Keputusan Direktorat
Jenderal Penguatan Riset dan Pengembangan,
Kementerian Riset, Teknologi dan Pendidikan Tinggi
Republik Indonesia
Nomor: 23/E/KPT/2019. 08 Agustus 2019
https://jurnal.umk.ac.id/index.php/kredo/index

Ungkapan Jawa merupakan bentuk ekspresi ide gagasan Jawa melalui katakata mutiara yang bernilai indah dan tinggi (Darmoko, 2018). Karena bernilai indah dan tinggi, ungkapan Jawa dikategorikan sebagai salah satu bentuk kesusastraan Jawa. Dalam kehidupan masyarakat Jawa, ungkapan Jawa digunakan dalam kehidupan sehari-hari untuk beraneka macam tujuan. Ungkapan Jawa mengandung nilai moral yang baik yang dapat dijadikan sebagai renungan dan pedoman bagi masyarakat Jawa.

Ada berbagai macam bentuk ungkapan Jawa, antara lain paribasan, bebasan, saloka, dan isbat (Darmoko, 2018). Paribasan adalah ungkapan bahasa Jawa yang telah memiliki pola dan makna tertentu, berupa susunan kata atau frasa yang tidak berubah dan biasanya mengandung makna kiasan. Paribasan mengandung perbandingan dan perumpamaan manusia, tindakan manusia, ataupun hubungan manusia dengan alam (Darmoko, 2018). Contoh ulat madhep ati karep, yang berarti tekad yang sudah sangat kuat, yakin dan mantap lahir batin.

Bebasan merupakan ungkapan Jawa yang berkaitan dengan sifat, sikap, dan tindakan manusia (Darmoko, 2018). Contoh rubuh-rubuh gedhang yang artinya orang yang bertindak karena ikut-ikutan, tidak mengetahui maksud dan tujuannya. Saloka merupakan perkataan yang menunjukkan keadaan manusia (Darmoko, 2018). Contohnya tumbu oleh tutup, yang bermakna seseorang yang sudah mendapatkan sesuatu yang cocok dengan keinginannya. Sedangkan isbat adalah ungkapan Jawa yang berkaitan dengan hal gaib atau supranatural (Darmoko, 2018). Contoh: golekana kayu gung susuhing angin yang berarti keinginan yang kuat akan tercapai jika kita mampu menguasai nafas, mampu mengendalikan diri.

\section{Sosiologi Sastra}

Damono (1978) bahwa sosiologi sastra merupakan salah satu pendekatan dalam penelitian sastra yang memahami dan menilai karya sastra dengan cara memperhitungkan segi-segi sosial kemasyarakatan, yaitu dengan cara memadukan antara ilmu sosiologi dengan ilmu sastra. Hal ini sesuai dengan apa yang dikemukakan oleh Ratna (2011) bahwa sosiologi sastra merupakan pemahaman karya sastra dengan mempertimbangkan aspek-aspek kemasyarakatan. dikemukakan oleh

Perkembangan sosiologi sastra didorong oleh kesadaran bahwa karya sastra harus difungsikan sama dengan aspek-aspek kebudayaan lainnya, dengan cara mengembalikan karya sastra ke tengah-tengah masyarakat dan memahaminya sebagai bagian yang tidak terpisahkan dengan sistem komunikasi secara keseluruhan. Hal ini berdasarkan pertimbangan bahwa karya sastra hidup 


\begin{tabular}{|c|c|c|} 
Kredo 4 (2021) \\
KREDO: Jurnal Ilmiah Bahasa dan Sastra \\
Terakreditasi Sinta 4 berdasarkan Keputusan Direktorat \\
Jenderal Penguatan Riset dan Pengembangan, \\
Kementerian Riset, Teknologi dan Pendidikan Tinggi \\
Republik Indonesia \\
Nomor: 23/E/KPT/2019. 08 Agustus 2019 \\
https://jurnal.umk.ac.id/index.php/kredo/index
\end{tabular}

dalam masyarakat menyerap aspekaspek kehidupan yang terjadi dalam masyarakat, yang pada gilirannya juga akan difungsikan oleh masyarakat.

Karya sastra dapat mencerminkan suatu kebudayaan tertentu. Sebagai representasi kebudayaan tertentu, menurut Swingewood \& Laurenson (1972) dan diulas oleh Wahyuni (2013), karya sastra bukan artefak, melainkan hasil proses dialektika pemikiran sehingga pengarang memiliki ruang yang luas untuk memainkan kepekaannya terhadap perasaan dan pengalaman melalui karyanya. Dalam hal ini pengarang memiliki ruang-ruang kosong untuk mengurangi atau menambahkan estetika sebuah kebenaran dalam karyanya.

\section{METODOLOGI PENELITIAN}

Dalam menganalisis nilai-nilai budaya Jawa yang terkandung dalam ungkapan Jawa berlatar rumah tangga pada novel Canting karya Fissilmi Hamida ini, peneliti menggunakan pendekatan sosiologi sastra. Menurut Swingewood \& Laurenson (1972), terdapat tiga perspektif berkaitan dengan sosiologi sastra, yaitu: (1) penelitian yang memandang karya sastra sebagai dokumen sosial yang di dalamnya merupakan refleksi situasi pada masa sastra tersebut diciptakan, (2) penelitian yang mengungkap sastra sebagai cermin situasi sosial penulisnya, dan (3) penelitian yang menangkap sastra sebagai manifestasi peristiwa sejarah dan keadaan sosial budaya (Endraswara, 2012) .

Analisis dengan pendekatan sosiologi sastra ini merupakan penelitian kualitatif. Menurut Taylor et al. (2016), metode penelitian kualitatif adalah prosedur penelitian yang menghasilkan data deskriptif, dalam bentuk kata-kata tertulis atau lisan dari objek dan perilaku yang diamati. Dalam meneliti karya sastra menurut Ratna (2011), sumber data penelitian kualitatif untuk sastra adalah karya naskah. Adapun data penelitiannya berupa dari teks-teks novel dalam bentuk kata-kata, kalimat, dan wacana.

Sumber data dalam penelitian ini adalah novel Canting karya Fissilmi Hamida cetakan keempat tahun 2020 dengan tebal 360 halaman yang diterbitkan oleh KMO Publishing. Data penelitian ini adalah semua kutipan yang berkaitan dengan nilai-nilai budaya Jawa dalam ungkapan Jawa Canting. Teknik pengumpulan data dalam penelitian ini adalah dengan menelaah isi dokumen yaitu analisis isi yang meliputi; membaca secara cermat dan berulang, mengidentifikasi, mencatat/memberi kode, memeriksa atau menyeleksi, dan memasukan data. Analisis data dalam penelitian ini mencakup interpretasi, analisis data, dan penyimpulan data sesuai dengan tujuan penelitian. 


\begin{tabular}{|c|c|c|}
\hline & $\begin{array}{c}\text { Kredo } 4(2021) \\
\text { KREDO: Jurnal Ilmiah Bahasa dan Sastra } \\
\text { Terakreditasi Sinta } 4 \text { berdasarkan Keputusan Direktorat } \\
\text { Jenderal Penguatan Riset dan Pengembangan, } \\
\text { Kementerian Riset, Teknologi dan Pendidikan Tinggi } \\
\text { Republik Indonesia } \\
\text { Nomor: 23/E/KPT/2019. 08 Agustus 2019 } \\
\text { https://jurnal.umk.ac.id/index.php/kredo/index }\end{array}$ & 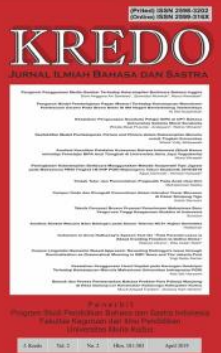 \\
\hline
\end{tabular}

\section{HASIL DAN PEMBAHASAN}

\section{Nilai-Nilai Budaya Jawa dalam Ungkapan-Ungkapan Jawa Berlatar Rumah Tangga dalam Novel Canting karya Fissilmi Hamida}

Dalam novel Canting karya Fissilmi Hamida terdapat nilai-nilai budaya Jawa yang berlatar rumah tangga. Nilai-nilai budaya Jawa tersebut adalah sebagai berikut:

\section{Nilai Keyakinan}

Nilai keyakinan berkaitan dengan masalah keyakinan seseorang dalam melakukan sesuatu. Dalam pandangan hidup Jawa, nilai keyakinan merupakan landasan penting bagi masyarakat untuk bersikap dan berperilaku. Masyarakat Jawa memiliki pemahaman khusus terhadap aspek keyakinan. Masyakat Jawa merupakan masyarakat yang berlandaskan pada nilai-nilai spiritual dalam setiap tindakannya. Masyarakat Jawa meyakini bahwa semua hal yang terjadi dalam kehidupan ini tidak luput dari kehendak Tuhan. Kaitannya dengan hubungan dengan sesama, nilai keyakinan berlandaskan pada hubungan saling percaya. Dengan saling percaya, masyarakat Jawa selalu menjaga pola kerukunan dengan sesama.

Ada tiga data ungkapan Jawa yang mengandung nilai keyakinan. Data ungkapan Jawa tersebut adalah sebagai berikut.
Tabel 1. Ungkapan Jawa yang mengandung nilai keyakinan

\begin{tabular}{|c|c|}
\hline Ungkapan Jawa & Arti \\
\hline $\begin{array}{l}\text { Gegaraning } \\
\text { wong akrami, } \\
\text { dudu banda, } \\
\text { dudu rupa, } \\
\text { amung ati } \\
\text { pawitane }\end{array}$ & $\begin{array}{l}\text { modalnya orang } \\
\text { menikah bukan } \\
\text { harta bukan fisik, } \\
\text { hanya hati yang } \\
\text { menjadi modal } \\
\text { utamanya atau } \\
\text { penentunya. }\end{array}$ \\
\hline $\begin{array}{l}\text { Gusti paring } \\
\text { dalan kanggo } \\
\text { wong sing } \\
\text { ngelam dalan }\end{array}$ & $\begin{array}{l}\text { Tuhan memberi } \\
\text { jalan untuk } \\
\text { manusia yang mau } \\
\text { mengikuti jalan } \\
\text { kebenaran. } \\
\text { Menjalani } \\
\text { kehidupan rumah } \\
\text { tangga bagaikan } \\
\text { bahtera yang } \\
\text { mengarungi } \\
\text { samudera. }\end{array}$ \\
\hline $\begin{array}{l}\text { Gusti paring } \\
\text { pitedah, bisa } \\
\text { lewat bungah, } \\
\text { bisa lewat } \\
\text { susah }\end{array}$ & $\begin{array}{l}\text { Tuhan akan } \\
\text { memberikan } \\
\text { petunjuk, bisa } \\
\text { melalui } \\
\text { kebahagiaan, bisa } \\
\text { juga melalui } \\
\text { kesusahan. }\end{array}$ \\
\hline
\end{tabular}

a. Gegaraning wong akrami, dudu banda, dudu rupa, amung ati pawitane

Menurut Rafiatun (2018) makna ungkapan gegaraning wong akrami, dudu banda, dudu rupa, amung ati pawitane adalah modalnya orang 


Kredo 4 (2021)
KREDO: Jurnal Ilmiah Bahasa dan Sastra
Terakreditasi Sinta 4 berdasarkan Keputusan Direktorat
Jenderal Penguatan Riset dan Pengembangan,
Kementerian Riset, Teknologi dan Pendidikan Tinggi
Republik Indonesia
Nomor: 23/E/KPT/2019. 08 Agustus 2019
https://jurnal.umk.ac.id/index.php/kredo/index

menikah bukan harta bukan fisik, hanya hati yang menjadi modal utamanya atau penentunya. Hal ini berarti yang menjadi landasan utama pernikahan bukanlah kekayaan ataupun rupa fisik pasangan, melainkan hati. Dengan kata lain, yang menjadi penentu kelangsungan dan kelanggengan pernikahan adalah akhlak dan budi pekerti yang baik. Tanpa adanya akhlak dan budi pekerti yang baik maka rumah tangga akan mudah tergoyahkan.

Dalam kehidupan sehari-hari, banyak fakta perceraian yang diakibatkan berbagai faktor seperti ketidakcocokan, perbedaan status sosial, faktor ekonomi, maupun perubahan fisik pasangan entah karena usia, penyakit tertentu, maupun kecelakaan. Hal tersebut tidak akan pernah terjadi jika setiap pasangan suami istri berpegang teguh pada ungkapan gegaraning wong akrami, dudu banda, dudu rupa, amung ati pawitane, saling mengerti dan memahami bahwa perubahan status sosial ekonomi ataupun perubahan fisik bukanlah alasan untuk meninggalkan peran dan tanggung jawab dalam rumah tangga.

Dalam novel Canting, ungkapan tersebut terdapat dalam kutipan berikut:

"Sekar, dengar ini. Gegaraning wong akrami, dudu banda, dudu rupa, amung ati pawitane." Kata Hadi. Sekar meletakkan gelas yang baru saja ia minum separuh isinya (Hamida, 2020, hal. 29).

Berdasarkan kutipan tersebut diketahui bahwa dalam membina rumah tangga, Hadi dan Sekar berdasarkan prinsi gegaraning wong akrami, dudu banda, dudu rupa, amung ati pawitane. Dalam memilih pasangan Hadi tidak memandang status sosial Sekar. Meskipun Sekar berstatus rewang, pembantu rumah tangga, tetapi Hadi bertekad menikahinya karena melihat kebaikan hati Sekar. Begitu pula halnya Sekar menerima Hadi karena bukan status sosial dan kekayaannya, tetapi karena ketulusan Hadi.

Oleh karena itu, ketika Hadi mengalami kebangkrutan dan kecelakaan, Sekar tetap setia, mengurus, dan mengabdi pada Hadi dengan sepenuh hati. Hal ini membuktikan bahwa yang melanggengkan pernikahan bukanlah kekayaan dan fisik semata, tetapi yang paling utama adalah akhlak dan budi pekerti yang baik.

\section{b. Gusti paring dalan kanggo wong sing ngelam dalan}

Arti ungkapan tersebut adalah Tuhan memberi jalan untuk manusia yang mau mengikuti jalan kebenaran. Menjalani kehidupan rumah tangga bagaikan bahtera yang mengarungi samudera. Pasti akan terkena angin dan gelombang yang menguji keutuhan rumah tangga. Ujian itu bisa berupa 


Kredo 4 (2021)
KREDO: Jurnal Ilmiah Bahasa dan Sastra
Terakreditasi Sinta 4 berdasarkan Keputusan Direktorat
Jenderal Penguatan Riset dan Pengembangan,
Kementerian Riset, Teknologi dan Pendidikan Tinggi
Republik Indonesia
Nomor: 23/E/KPT/2019. 08 Agustus 2019
https://jurnal.umk.ac.id/index.php/kredo/index

masalah ekonomi, konflik, masalah keluarga, dan sebagainya.

Namun, dengan keyakinan bahwa Gusti paring dalan kanggo wong sing ngelam dalan, yakin bahwa Tuhan akan memberikan jalan bagi manusia yang berada di jalan kebenaran, segala ujian itu akan dapat diatasi dengan baik karena Tuhan pasti akan memberikan petunjuk dan jalan keluar.

Dalam novel Canting, ungkapan tersebut terdapat dalam kutipan berikut:

Meski hidup mereka serba kekurangan, namun mereka percaya bahwa Gusti paring dalan kanggo wong sing gelem ngelam ndalan, bahwa akan ada jalan bagi mereka yang berada di jalan kebenaran, termasuk jalan mencari rezeki halal (Hamida, 2020, hal. 177).

Dari kutipan tersebut diketahui bahwa ungkapan tersebut dipegang teguh oleh orang tua Sundari, nenek Hadi, yang berjuang keras untuk mencari rezeki halal guna menafkahi keluarganya. Pada awalnya orang tua Sundari hanyalah pedagang kecil. Ia berjualan batik dengan cara berkeliling dari rumah ke rumah. Meskipun hidup serba kekurangan mereka selalu percaya bahwa Gusti paring dalan kanggo wong sing ngelam dalan, Tuhan akan memberi jalan bagi mereka yang berada di jalan kebenaran. Perlahan keyakinan dan kegigihan mereka berbuah manis.
Perlahan dari yang awalnya pedagang keliling, mereka punya kios sederhana. Semakin hari semakin jaya, hingga lahirlah The Sundari House, brand batik mereka sendiri. Usaha mereka tersebut tumbuh dan berkembang pesat sehingga tidak hanya mampu menafkahi keluarganya, tetapi juga menghidupi beberapa keluarga lain yang menjadi tenaga kerjanya.

\section{c. Gusti paring pitedah, bisa lewat bungah, bisa lewat susah}

Ungkapan tersebut bermakna bahwa Tuhan akan memberikan petunjuk, bisa melalui kebahagiaan, bisa juga melalui kesusahan. Kehidupan rumah tangga itu bagaikan roda yang berputar. Kadang berada di atas, kadang berada di bawah. Kadang Tuhan menguji kita bahagia dan anugerah, kadang menguji kita dengan kesusahan dan musibah. Akan tetapi, dalam keadaan apapun, Tuhan akan selalu hadir di tengah-tengah kita. Dia akan membimbing dan memberikan kita petunjuk. Oleh karena itu, dalam menghadapi berbagai peristiwa dalam kehidupan rumah tangga, hendaknya kita selalu mengingat keberadaan Tuhan.

Dalam menghadapi kebahagiaan, kita tetap bersikap eling, ingat pada Tuhan, sehingga kita senantiasa bersyukur, tetapi juga bersikap sewajarnya dan tidak berlebih-lebihan. Begitu pula saat kita ditimpa musibah, hendaknya bersabar dan tidak mudah 


Kredo 4 (2021)
KREDO: Jurnal Ilmiah Bahasa dan Sastra
Terakreditasi Sinta 4 berdasarkan Keputusan Direktorat
Jenderal Penguatan Riset dan Pengembangan,
Kementerian Riset, Teknologi dan Pendidikan Tinggi
Republik Indonesia
Nomor: 23/E/KPT/2019. 08 Agustus 2019
https://jurnal.umk.ac.id/index.php/kredo/index

putus asa, karena Tuhan selalu bersama kita, memberikan petunjuk dan jalan keluar dalam kehidupan kita.

Dalam novel Canting, ungkapan ini ditulis secara eksplisit sebagai berikut:

\section{Gusti paring pitedah}

Bisa lewat bungah, bisa lewat susah

Tuhan memberikan ujian

Bisa melalui kebahagiaan, bisa melalui kesusahan (Hamida, 2020, hal. 213)

Hamida menggunakan ungkapan ini untuk menggambarkan kehidupan rumah tangga Hadi dan Sekar yang terus mengalami musibah. Gudang pabrik batik yang terbakar, kecelakaan yang dialami Hadi, dan juga kehadiran wanita pengganggu. Namun, keduanya tetap bersabar, berusaha mengambil hikmah dari setiap ujian yang mereka alami dan selalu bersemangat untuk berusaha lebih baik lagi. Terutama Sekar, berbagai masalah yang menimpanya justru menumbuhkan pribadinya yang semakin kuat, percaya diri, bermimpi besar, dan berani maju. Hal demikian terdapat dalam kutipan berikut:

"Aku bangga padamu, Sayang. Lihat dirimu sekarang. Aku masih ingat bagaimana Sekar yang selalu rendah diri, yang selalu merasa tak pantas mendampingi seorang Hadi. Tapi seiring berhasilnya kamu melewati masalah-masalah yang menghampiri, aku bisa melihat kamu sudah tumbuh menjadi Sekar yang jauh lebih kuat, jauh lebih percaya diri. Rasanya tidak percaya Sekar yang selalu rendah diri, sekarang bisa menjelaskan mimpi besarnya seperti ini,"pujinya sambil kembali menghadiahkan sebuah kecupan mesra (Hamida, 2020, hal. 224).

Dari kutipan tersebut diketahui bahwa masalah-masalah yang dihadapi oleh Sekar justru menumbuhkan pribadinya yang semakin kuat, percaya diri, berani maju dan bermimpi besar. Hal ini berarti bahwa makna ungkapan Gusti paring pitedah, bisa lewat bungah, bisa lewat susah adalah dalam setiap ujian yang Tuhan berikan, baik bahagia maupun susah, pasti mengandung hikmah. Melalui masalahmasalah yang Tuhan hadirkan, pada dasarnya dididik agar kita menjadi semakin teguh dan kuat.

\section{Nilai Kesabaran}

Sudah diuraikan sebelumnya bahwa masyarakat Jawa meyakini bahwa segala yang terjadi dalam kehidupan manusia merupakan kehendak Tuhan. Oleh karena itu, manusia hendaknya bersikap rila, nerima, dan sabar. Sabar merupakan kelapangan dada, yang dapat merangkul segala pertentangan dan perbedaan. Kesabaran diartikan sebagai sikap 


\begin{tabular}{|c|c|c|} 
Kredo 4 (2021) \\
KREDO: Jurnal Ilmiah Bahasa dan Sastra \\
Terakreditasi Sinta 4 berdasarkan Keputusan Direktorat \\
Jenderal Penguatan Riset dan Pengembangan, \\
Kementerian Riset, Teknologi dan Pendidikan Tinggi \\
Republik Indonesia \\
Nomor: 23/E/KPT/2019. 08 Agustus 2019 \\
https://jurnal.umk.ac.id/index.php/kredo/index
\end{tabular}

pengekangan diri yang paling tinggi. Barangsiapa yang bersikap sabar tidak tergoncangkan dan tidak diombangambingkan oleh apa saja yang dijumpainya. Ia tidak menceraiberaikan dan tidak akan terceraiberaikan (De Jong, 1976).

Ada tiga data ungkapan Jawa yang mengandung nilai keyakinan. Ungkapan Jawa tersebut adalah sebagai berikut.

Tabel 2. Ungkapan Jawa yang mengandung nilai keyakinan

\begin{tabular}{|c|c|}
\hline Ungkapan Jawa & Arti \\
\hline $\begin{array}{l}\text { Wani ngalah } \\
\text { luhur } \\
\text { wekasane }\end{array}$ & $\begin{array}{l}\text { berani mengalah, } \\
\text { mulia pada } \\
\text { akhirnya. }\end{array}$ \\
\hline $\begin{array}{l}\text { Aja obah yen } \\
\text { atimu } \\
\text { kemrayah, } \\
\text { aluwung } \\
\text { meneng nganti } \\
\text { atimu lerem }\end{array}$ & $\begin{array}{l}\text { jangan bertindak } \\
\text { saat hatimu didera } \\
\text { emosi, lebih baik } \\
\text { diam sampai } \\
\text { hatimu tenang } \\
\text { kembali }\end{array}$ \\
\hline $\begin{array}{l}\text { Sura dira } \\
\text { jayaningrat, } \\
\text { lebur dening } \\
\text { pangastuti }\end{array}$ & $\begin{array}{lr}\begin{array}{l}\text { segala sifat } \\
\text { hati, }\end{array} & \text { peras } \\
\text { angkara } & \text { murka } \\
\text { hanya } & \text { bisa } \\
\text { dikalahkan } & \text { oleh } \\
\text { sikap } & \text { bijak, } \\
\text { lembut hati dan } \\
\text { sabar. }\end{array}$ \\
\hline
\end{tabular}

\section{a. Wani ngalah luhur wekasane}

Wani ngalah luhur wekasane berarti berani mengalah, mulia pada akhirnya. Ungkapan ini berarti bahwa kesadaran seseorang untuk berani menghadapi benturan kekerasan dengan orang lain dengan sikap dan tindakan yang didasari rasa ikhlas, sabar, jujur, dan kasih sayang. Hal ini semata-mata demi mewujudkan kedamaian hidup bersama, agar di kemudian hari menikmati hidup yang luhur dan mulia (Departemen Kebudayaan dan Pariwisata, 2007).

Dalam rumah tangga, kebahagiaan dan keharmonisan adalah tujuan utama. Namun, untuk mencapai tujuan tersebut tidak mudah karena memerlukan kualitas interaksi antarpribadi yang baik. Dalam rumah tangga terkadang apa yang diharapkan oleh masingmasing individu tidak sesuai dengan kenyataannya yang dihadapi.

Kehidupan rumah tangga harmonis, menuntut adanya perubahan gaya hidup, penyesuaian diri terhadap peran dan tanggung jawab baru baik dari suami maupun istri. Ketidakmampuan untuk melakukan tuntutan-tuntutan tersebut tidak jarang menimbulkan pertentangan dan perselisihan. Wani ngalah, merupakan salah satu cara untuk mengurangi dan mengatasi konflik dalam rumah tangga. Ngalah bukan berarti kalah, tetapi semata-mata untuk menjaga keharmonisan, ketentraman, dan kelanggengan dalam rumah tangga.

Dalam novel Canting, konflik ini digambarkan melalui tokoh Sekar. Sekar tidak ingin menikah di usia muda karena masih memiliki cita-cita untuk 


Kredo 4 (2021)
KREDO: Jurnal Ilmiah Bahasa dan Sastra
Terakreditasi Sinta 4 berdasarkan Keputusan Direktorat
Jenderal Penguatan Riset dan Pengembangan,
Kementerian Riset, Teknologi dan Pendidikan Tinggi
Republik Indonesia
Nomor: 23/E/KPT/2019. 08 Agustus 2019
https://jurnal.umk.ac.id/index.php/kredo/index

melanjutkan pendidikannya ke perguruan tinggi agar menjadi orang yang berguna. Namun, Sekar merasa tidak berdaya menghadapi kemauan ayahnya untuk menerima pinangan Hadi. Namun, Simbok, ibu Sekar, selalu menasihati untuk mengalah pada kemauannya ayahnya, wani ngalah luhur wekasane, berani mengalah mulia pada akhirnya. Dalam pandangan Simbok, menikah bukanlah hal buruk dan tidak akan membuat cita-cita akan hancur. Apalagi jika pasangan kita adalah orang baik, dia pasti akan membimbing kita agar menjadi lebih maju.

Wani ngalah luhur wekasane, ungkapan ini selalu dipegang oleh Sekar, tidak hanya ketika menghadapi ayahnya, tetapi juga ketika menjalani rumah tangganya. Terhadap suaminya, Sekar selalu bersikap sabar, mengayomi, dan berbakti sehingga Hadi terdorong dengan tulus hati memberikan peluang Sekar untuk maju. Hadi mendorong dan membimbing Sekar untuk melanjutkan pendidikannya di luar negeri sesuai dengan cita-cita Sekar selama ini.

Hal tersebut terdapat dalam kutipan berikut:

Benarlah wejangan andalan simbok yang selalu dipetuahkan padanya. Eling Nduk. Wani ngalah dhuwur wekasane. Berani mengalah itu akan mendatangkan kemuliaan. Lagi pula yang kita anggap baik, belum tentu baik di mata Gusti Pangeran. Yang harus kita lakukan adalah nerimo lan nglakoni, menerima dan menjalani. Sekar tersenyum penuh arti. Ia memejamkan mata dalam pelukan Hadi yang dinginnya hawa tak begitu terasa, sembari menyibak lembar demi lembar perjalanannyaa. Sungguh, jalan ini, dahulu ia sama sekali tak menginginkannya. Bahkan ia berontak, tak ingin menerimanya. Namun, siapa sangka ternyata semua ini adalah jalan yang dibutuhkannya, jalan yang terbaik baginya (Hamida, 2020, hal. 308).

Dari kutipan tersebut diketahui bahwa Sekar membuktikan kebenaran wejangan Simbok tentang wani ngalah luhur wekasane. Pada awalnya, Sekar tidak menginginkan, berontak, dan tidak mau menerima pernikahan di usia muda. Namun, atas nasihat ibunya, Sekarpun akhirnya mengalah. Setelah bersikap mengalah, mengalah pada kemauan ayahnya, mengalah pada suaminya, jalan yang ia butuhkan untuk melanjutkan pendidikan justru terbuka lebar. Melalui bimbingan suaminya, Sekar dapat melanjutkan pendidikan di perguruan tinggi luar negeri, jurusan seni desainer, sesuai dengan minatnya. 


Kredo 4 (2021)
KREDO: Jurnal Ilmiah Bahasa dan Sastra
Terakreditasi Sinta 4 berdasarkan Keputusan Direktorat
Jenderal Penguatan Riset dan Pengembangan,
Kementerian Riset, Teknologi dan Pendidikan Tinggi
Republik Indonesia
Nomor: 23/E/KPT/2019. 08 Agustus 2019
https://jurnal.umk.ac.id/index.php/kredo/index

\section{b. Aja obah yen atimu kemrayah, aluwung meneng nganti atimu lerem}

Arti ungkapan tersebut adalah jangan bertindak saat hatimu didera emosi, lebih baik diam sampai hatimu tenang kembali (Hamida, 2020, hal. 243). Menurut Sari (2016), maksud dari ungkapan tersebut adalah dalam menyelesaikan masalah harus senantiasa bertindak hati-hati, terlebih lagi pada saat emosi menyelimuti hati. Emosi memiliki arti luapan perasaan yang berkembang dan surut dalam waktu yang singkat.

Pada saat kita dipenuhi dengan gejolak amarah, yang pertama kita lakukan adalah menenangkan diri, bukan mengambil tindakan. Hal ini karena tindakan yang dilakukan dalam keadaan terburu-buru dan penuh amarah, justru akan membahayakan, bahkan dapat berakhir fatal dan merugikan diri sendiri. Sebaliknya, dengan bersikap tenang, menjernihkan hati dan pikiran, segala sesuatu yang kita lakukan dapat dipertimbangkan dahulu sehingga dapat membawa kebaikan.

Ungkapan ini digambarkan oleh tokoh Sekar ketika menghadapi Ajeng. Dalam menghadapi Ajeng, Sekar senantiasa berusaha mengendalikan dirinya. Ia berusaha bersikap halus dan tenang, meskipun hatinya penuh gejolak. Hal tersebut terdapat dalam kutipan berikut:

\section{5 | Jurnal Kredo}

Vol. 4 No. 22021
Sekar memejamkan mata, lalu menghela nafas panjang, berusaha meredam api hatinya yang masih terus membesar. Ubun-ubunnya terasa mendidih, dadanya begitu sesak, nafasnya tersengal, ia sungguh kesal. Ingin rasanya ia berdiri dan menumpahkan segelas minumannya tepat di wajah Ajeng, lalu menjambaknya, dan membenturbenturkan kepalanya di meja agar Ajeng sadar, apa yang dilakukannya sangat menyakiti hatinya, agar semua orang tahu bahwa perempuan di hadapannya adalah perempuan tak tahu diri yang terus mengejar seorang lelaki yang telah beristri.

Tapi yang ia lakukan hanyalah diam, berusaha menenangkan diri seperti yang dilakukan Hadi saat didera emosi. Ia ingat wejangan Hadi agar jangan pernah bertindak kala hati diselimuti emosi, sebab seringkali tindakan yang dilakukan saat hati dipenuhi emosi tinggi justru akan merugikan diri sendir (Hamida, 2020, hal. 243-244).

Dari kutipan itu diketahui bahwa meskipun Sekar sangat marah kepada Ajeng, ia tidak melampiaskan emosinya secara frontal dengan berkata kasar ataupun kekerasan. Sekar sadar jika ia berbuat kekerasan kepada Ajeng justru akan berakibat fatal dan merugikan dirinya sendiri, misalnya mencemarkan nama baik dirinya ataupun bisa saja 


Kredo 4 (2021)
KREDO: Jurnal Ilmiah Bahasa dan Sastra
Terakreditasi Sinta 4 berdasarkan Keputusan Direktorat
Jenderal Penguatan Riset dan Pengembangan,
Kementerian Riset, Teknologi dan Pendidikan Tinggi
Republik Indonesia
Nomor: 23/E/KPT/2019. 08 Agustus 2019
https://jurnal.umk.ac.id/index.php/kredo/index

justru ia yang mendekam dalam penjara. Sebaliknya, Sekar berusaha mengendalikan dirinya. Ia bersikap halus, tenang, elegan, tetapi juga sangat tegas menghadapi Ajeng.

\section{c. Sura dira jayaningrat, lebur dening pangastuti}

Menurut Mustikarini (2013), ungkapan sura dira jayaningrat, lebur dening pangastuti berarti segala sifat keras hati, picik, angkara murka hanya bisa dikalahkan oleh sikap bijak, lembut hati dan sabar. Mustikarini (2013), Firmansyah (2013), dan Wibisono (2020) mengatakan bahwa ungkapan sura dira jayaningrat, lebur dening pangastuti maksudnya manusia hidup di dunia harus mengusahakan keselamatan, kebahagiaan dan kesejahteraan. Dalam melakukan hal apapun manusia hendaknya selalu mengutamakan keselamatan dan bertujuan untuk mendapatkan kebahagiaan dan kesejahteraan.

Menurut Darmoko (2018), ungkapan ini memuat kandungan makna bahwa manusia meletakkan Tuhan sebagai dzat yang tertinggi, sehingga dalam menghadapi segala urusan duniawi yang bersifat 'kuasa' dan 'menguasai' sepenuhnya diserahkan kepada Tuhan yang Maha Tinggi. Begitu juga dalam konteks rumah tangga, setiap orang hendaknya mengutamakan keutuhan, keharmonisan, dan keharmonisan rumah tangganya. Apabila terjadi konflik dan pertentangan, hendaknya disikapi dengan sabar, tenang, lemah lembut, dan elegan.

Dalam novel Canting, ungkapan tersebut terdapat dalam kutipan berikut:

Bapak menyadari kekeliruannya saat menyaksikan sendiri betapa tulus Sekar merawatnya yang sudah tak lagi mampu lagi berjalan seperti sedia kala. Sekar rela meninggalkan semua pekerjaan demi merawatnya, mulai menyuapi, memandikan, bahkan sampai membersihkan kotorannya. Maka benarlah pepatah yang berbunyi suradira jayaningrat lebur dening pangastuti, bahwa segala angkara murka akan luluh dengan kelembutan hati (Hamida, 2020, hal. 304).

Dari kutipan tersebut diketahui bahwa Sekar selalu bersikap tulus ikhlas dan lembut hati kepada ayahnya. Ketika ayahnya sakit, Sekar dengan sepenuh hati merawatnya. Ketulusan dan kelembutan hati Sekar yang demikian meluluhkan hati ayahnya. Pada awalnya ayah Sekar menganggap Sekar sebagai anak yang tidak berguna karena tidak mampu memenuhi harapannya untuk memberi harta kekayaan dari pernikahnnya dengan Hadi. Ayah Sekar juga bersikap keras dan kasar terhadap anaknya. Namun, karena dihadapi dengan kesabaran dan ketulusan, 


Kredo 4 (2021)
KREDO: Jurnal Ilmiah Bahasa dan Sastra
Terakreditasi Sinta 4 berdasarkan Keputusan Direktorat
Jenderal Penguatan Riset dan Pengembangan,
Kementerian Riset, Teknologi dan Pendidikan Tinggi
Republik Indonesia
Nomor: 23/E/KPT/2019. 08 Agustus 2019
https://jurnal.umk.ac.id/index.php/kredo/index

akhirnya Ayah Sekar menyadari kekeliruannya.

Demikianlah yang terjadi dalam rumah tangga. Akan selalu ada pihak ketiga yang hadir dan berusaha untuk merusak kebahagiaan rumah tangga. Pihak ketiga tersebut tidak selalu identik wanita atau pria idaman lain, tetapi bisa juga dari orang tua, mertua, saudara ipar, dan sebagainya. Dalam menghadapi pihak ketiga ini, hendaknya kita tetap senantiasa teguh pada ungkapan suradira jayaningrat lebur dening pangastuti. Tidak membalas kejahatan dengan kejahatan, tetapi dengan senantiasa berbuat penuh kebaikan.

\section{Nilai Pencapaian (Harapan dan Cita-Cita)}

Nilai pencapaian menitikberatkan pada aspek bagaimana usaha manusia mencapai sebuah pengharapan. Nilai pencapaian ini mengantarkan manusia agar memperjuangkan apa yang menjadi harapan dalam kehidupannya. Adapun wujud ikhtiar yang dilakukan tidak hanya dengan upaya, tetapi juga doa dan permohonan. Ada lima data ungkapan Jawa yang mengandung nilai pencapaian sebagaimana pada tabel berikut:

Tabel 3. Ungkapan Jawa yang mengandung nilai keyakinan

\begin{tabular}{|l|l|}
\hline Ungkapan Jawa & Arti \\
\hline Gulo, & Mengelola \\
\hline
\end{tabular}

567 | Jurnal Kredo

Vol. 4 No. 22021

\begin{tabular}{|l|l|}
\hline gulangane rasa & $\begin{array}{l}\text { perasaan dengan } \\
\text { baik }\end{array}$ \\
\hline $\begin{array}{l}\text { Udhek tegese } \\
\text { usahane } \begin{array}{l}\text { aja } \\
\text { nganti mandhek }\end{array}\end{array}$ & $\begin{array}{l}\text { Sampanya jangan } \\
\text { samenti }\end{array}$ \\
\hline $\begin{array}{l}\text { Sendhok, } \\
\text { sendhekno } \\
\text { marang sing } \\
\text { kuasa }\end{array}$ & $\begin{array}{l}\text { Sandarkan pada } \\
\text { Yang Maha Kuasa }\end{array}$ \\
$\begin{array}{l}\text { Adem, ati } \\
\text { digawa lerem }\end{array}$ & Hati dibawa tenan \\
\hline $\begin{array}{l}\text { Seruput, sedaya } \\
\text { rubeda bakal } \\
\text { luput }\end{array}$ & $\begin{array}{l}\text { Segala godan terhindar. } \\
\text { akan }\end{array}$ \\
\hline
\end{tabular}

\section{a. Gula, gulangane rasa}

Artinya mengelola perasaan dengan baik (Hamida,2020, hal.90). Ungkapan tersebut memiliki makna bahwa dalam kehidupan ini kadang terasa pahit, menderita. Begitu pula, dalam rumah tangga, terkadang kita merasa susah dan terpuruk. Namun, hal tersebut dapat kita atasi jika kita mampu mengelola perasaan dengan baik. Dalam novel Canting, hal tersebut terdapat dalam kutipan berikut:

"Begitu juga dengan kehidupan ini. Kadang akan terasa begitu pahit. Tapi sepahit-pahitnya kopi, kita bisa membuatnya manis dengan cara menambahkan gula. Gula dalam bahasa Jawa disebut gulo, artinya gulangane roso atau mengelola perasaan baik. Apapun yang terjadi, khusnudhon, selalu berprasangka baik. Kehidupan 


Kredo 4 (2021)
KREDO: Jurnal Ilmiah Bahasa dan Sastra
Terakreditasi Sinta 4 berdasarkan Keputusan Direktorat
Jenderal Penguatan Riset dan Pengembangan,
Kementerian Riset, Teknologi dan Pendidikan Tinggi
Republik Indonesia
Nomor: 23/E/KPT/2019. 08 Agustus 2019
https://jurnal.umk.ac.id/index.php/kredo/index

yang pahit, tak akan terasa begitu sulit saat kita berprasangka baik pada Gusti Pangeran.”

(Hamida, 90)

Dari kutipan tersebut diketahui bahwa dalam menjalankan biduk rumah tangga, hendaknya kita selalu berprasangka baik pada Tuhan Yang Maha Kuasa. Apapun yang terjadi, berpikir positif bahwa Tuhan sedang merencanakan sesuatu yang baik untuk kita. Dengan berpikir demikian, kehidupan yang terasa berat akan terasa lebih ringan dan membuat kita lebih bahagia.

\section{b. Udhek tegese usahane aja nganti mandhek}

Artinya usahanya jangan sampai berhenti (Hamida,2020, hal. 90). Ungkapan ini mengandung arti bahwa keharmonisan dalam rumah tangga membutuhkan usaha dan perjuangan. Udhek, usahane aja nganti mandhek merupakan ajaran agar kita selalu memperjuangkan keharmonisan tersebut tanpa henti. Jika rumah tangga dilanda masalah ekonomi, maka suami istri hendaknya berupaya lebih giat lagi dalam bekerja. Jika rumah tangga didatangi oleh pihak ketiga yang berusaha mengganggu, maka suami istri hendaknya semakin gigih berusaha untuk setia terhadap pasangan. Demikian juga jika ada masalah lainnya, hendaknya diupayakan untuk dicari jalan keluarnya dengan sebaik-baiknya, terus-menerus tanpa henti, guna mempertahankan kebahagiaan rumah tangga tersebut.

Dalam novel Canting, ungkapan tersebut terdapat dalam kutipan berikut:

\begin{abstract}
"Kita analogikan situasi kita yang sekarang dengan kopi yang pahit. Kita membuatnya menjadi manis dengan menambahkan gula. Agar tercampur, gula ini harus diaduk, diudhek. Udhek tegese usahane aja nganti mandhek. Ikhitiar kita tidak boleh berhenti. Begitu juga usaha kita dalam membina rumah tangga kita (Hamida, 2020, hal. 142).
\end{abstract}

Dari kutipan tersebut dapat diketahui bahwa situasi rumah tangga yang Sekar dan Hadi jalani sedang pahit, penuh kesusahan. Namun, Hadi menasihati Sekar bahwa situasi tersebut dapat berubah menjadi lebih baik denganjalan berikhtiar. Ikhtiar tersebut harus dilakukan terus-menerus tanpa henti. Hal ini berarti bahwa kebahagiaan dalam rumah tangga adalah sesuatu yang harus senantiasa diusahakan terus menerus tanpa henti.

\section{b. Sendhok, sendhekno marang sing kuasa}

Ungkapan tersebut artinya sandarkan pada Yang Maha Kuasa (Hamida, 2020, hal. 142). Ungkapan ini bermakna bahwa setelah segala usaha diupayakan dengan sebaik-baiknya, 


\begin{tabular}{|c|c|c|} 
Kredo 4 (2021) \\
KREDO: Jurnal Ilmiah Bahasa dan Sastra \\
Terakreditasi Sinta 4 berdasarkan Keputusan Direktorat \\
Jenderal Penguatan Riset dan Pengembangan, \\
Kementerian Riset, Teknologi dan Pendidikan Tinggi \\
Republik Indonesia \\
Nomor: 23/E/KPT/2019. 08 Agustus 2019 \\
https://jurnal.umk.ac.id/index.php/kredo/index
\end{tabular}

langkah selanjutnya adalah menyerahkan segalanya pada Tuhan Yang Maka Kuasa. Menyerahkan segalanya pada Tuhan bukan berarti pasrah, melainkan meyakini bahwa Tuhan Maha Menentukan. Oleh karena itu, selain memperbanyak doa dan permohonan pada Tuhan agar keharmonisan rumah tangga senantiasa terjaga.

Dalam novel Canting, ungkapan tersebut terdapat dalam kalimat berikut:

“...Nah, untuk mengaduk, kita perlu sendok, artinya sendhekno marang sing kuasa, serahkan pada Yang Maha Kuasa. Kewajiban kita setelah ikhtiar adalah menyerahkannya pada yang Kuasa kan? Kencangkan doa kita, perbanyak permohonan kita agar senantiasa terjaga" (Hamida, 2020, hal. 142).

Kutipan tersebut merupakan lanjutan nasihat Hadi kepada Sekar. Ungkapan tersebut sendhok, sendhekno marang sing kuasa bermakna bahwa kita berikhtiar membina rumah tangga dengan sebaik-baiknya, tetapi kita tetapkan menyerahkan apa yang telah kita usahakan kepada Tuhan. Kita meyakini bahwa ada campur tangan Tuhan dalam setiap kejadian dalam kehidupan kita. Oleh karena itu, dalam membina rumah tangga kita juga jangan pernah berhenti berdoa dan meminta permohonan pada Tuhan Yang Kuasa agar rumah tangga kita senantiasa terlindungi dari segala gangguan.

\section{c. Adem, ati digawa lerem}

Artinya hati dibawa tenang. Dalam novel Canting, ungkapan ini terdapat dalam kutipan berikut:

"Setelah itu, kita tunggu kopi tadi agar lebih adem agar kita bisa meminumnya. Adem, artinya ati digowo lerem. Tenangkan hati kita karena kita sudah ikhtiar dan memasrahkannya pada yang kuasa, agar tidak ada lagi prasangka yang dapat merusak semuanya (Hamida, 2020, hal. 143).

Berdasarkan kutipan tersebut ungkapan ini mengandung makna bahwa setelah ikhtiar dan berdoa dengan sebaik-baiknya, langkah selanjutnya adalah menenangkan hati. Menenangkan hati berguna sebagai pengendalian diri agar selalu berpikir baik dan melahirkan perilaku yang baik pula sehingga tidak memperburuk keadaan. Menenangkan hati akan berguna untuk menjaga keadaan senantiasa tenang, tenteram, dan harmonis.

\section{d. Seruput, sedaya rubeda bakal luput}

Artinya segala godaan akan terhindar. Dalam novel Canting, ungkapan tersebut terdapat dalam kalimat berikut: 


Kredo 4 (2021)
KREDO: Jurnal Ilmiah Bahasa dan Sastra
Terakreditasi Sinta 4 berdasarkan Keputusan Direktorat
Jenderal Penguatan Riset dan Pengembangan,
Kementerian Riset, Teknologi dan Pendidikan Tinggi
Republik Indonesia
Nomor: 23/E/KPT/2019. 08 Agustus 2019
https://jurnal.umk.ac.id/index.php/kredo/index

“...Jika kita bisa melewati semua proses ini, saatnya kopi itu diseruput. Seruput, sedaya rubeda bakal luput, segala godaan mudah-mudahan akan terhindar. " (Hamida, 2020, hal. 143)

Dari kutipan tersebut dapat diketahui bahwa ketika menghadapi situasi sulit, kita sudah beriktiar semaksimal mungkin, berdoa dan memohon pada Tuhan, menyerahkan segalanya pada Tuhan, dan menenangkan hati kita agar keadaan senantiasa tentram dan harmonis. Dengan izin Tuhan segala godaan dalam rumah tangga pasti dapat diatasi dengan sebaik-baiknya.

\section{Nilai Keselarasan}

Paham masyarakat Jawa selalu berlandaskan pada keselarasan hidup. Oleh karena itu, budaya Jawa selalu menganjurkan masyarakatnya untuk selalu berbuat kebaikan. Setiap individu diharapkan selalu menjaga hubungan baik dengan sesamanya.

Ada empat data ungkapan Jawa yang mengandung nilai keselarasan. Ungkapan Jawa tersebut adalah sebagaimana tabel berikut.

Tabel 4. Ungkapan Jawa yang mengandung nilai keyakinan

\begin{tabular}{|l|lr|}
\hline \multicolumn{1}{|c|}{ Ungkapan Jawa } & \multicolumn{2}{|c|}{ Artinya } \\
\hline Tresna kuwi kaya & cinta itu seperti \\
criping tela. Isa & keripik ubi. Bisa \\
ajur yen ora ngati- & hancur rika \\
ngati le nggawa & membawanya \\
\hline
\end{tabular}

\begin{tabular}{|l|l|}
\hline & tidak hati-hati \\
\hline $\begin{array}{l}\text { Datan serik lamun } \\
\text { ketaman, datan } \\
\text { susah lamun } \\
\text { kelangan }\end{array}$ & $\begin{array}{l}\text { jangan gampang } \\
\text { sakit hati manakala } \\
\text { musibah menimpa } \\
\text { diri, jangan terlalu } \\
\text { susah manakala } \\
\text { kehilangan sesuatu }\end{array}$ \\
\hline $\begin{array}{l}\text { Mimi lan mintuna } \\
\text { binatang yang } \\
\text { tidakr pernah } \\
\text { berpisah satu sama } \\
\text { lain. }\end{array}$ \\
$\begin{array}{l}\text { Urip rekasa } \\
\text { gelem, mukti uga } \\
\text { bisa, sabaya } \\
\text { mukti, sabaya pati } \\
\text { mau, bahagia juga } \\
\text { bisa, sehidup } \\
\text { semati dalam suka } \\
\text { maupun duka. }\end{array}$ \\
\hline
\end{tabular}

a. Tresna kuwi kaya criping tela. Isa ajur yen ora ngati-ngati le nggawa

Artinya cinta itu seperti keripik ubi. Bisa hancur jika membawanya tidak hati-hati. Makna dari ungkapan ini adalah bahwa cinta terkadang bagaikan keripik ubi, sesuatu sangat rapuh dan mudah retak (Mulyani, 2019). Jika kita tidak mampu mengelolanya dengan baik, ia akan hancur berkepingkeping. Bahkan mampu menyiksa dan menghancurkan diri sendiri.

Dalam novel Canting, ungkapan tersebut terdapat dalam kutipan berikut:

Ajeng kemudian berlalu, tanpa peduli lagi bahwa cintanya yang dulu murni, kini berubah menjadi obsesi, bahwa cintanya yang dulu ia jaga dalam diamnya, kini menjelma menjadi 


\begin{tabular}{|c|c|c|}
\hline & $\begin{array}{c}\text { Kredo } 4(2021) \\
\text { KREDO: Jurnal Ilmiah Bahasa dan Sastra } \\
\text { Terakreditasi Sinta } 4 \text { berdasarkan Keputusan Direktorat } \\
\text { Jenderal Penguatan Riset dan Pengembangan, } \\
\text { Kementerian Riset, Teknologi dan Pendidikan Tinggi } \\
\text { Republik Indonesia } \\
\text { Nomor: 23/E/KPT/2019. 08 Agustus 2019 } \\
\text { https://jurnal.umk.ac.id/index.php/kredo/index }\end{array}$ & 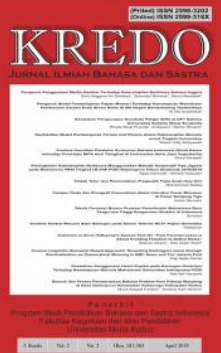 \\
\hline
\end{tabular}

cinta yang mungkin saja akan menghancurkan dirinya. Ajeng betulbetul lupa petuah Hadi,

"Tresna kuwi kaya criping tela. Isa ajur yen kowe ora ati-ati le nggawa." (Hamida, 2020, hal. 107)

Dari ungkapan tersebut diketahui bahwa pada awalnya cinta Ajeng kepada Hadi merupakan cinta yang murni. Namun, ketidakmampuan Ajeng dalam mengelola rasa cintanya menyebabkan cintanya berubah menjadi obsesi. Ajeng ingin memiliki Hadi. Ia tidak peduli Hadi sudah menikah. Karena ketidakmampuan dalam mengelola cinta, Ajeng merasa hidupnya sangat menderita. Ia berbuat nekat mengganggu biduk rumah tangga Sekar dan Hadi. Dari mulai sering menelepon Hadi, mendatangi Hadi ke rumahnya, bahkan tanpa malu meminta agar dipoligami. Hal ini tentu sangat mengganggu keharmoniasan rumah tangga Hadi dan Sekar. Berdasarkan uraian tersebut, disimpulkan bahwa ungkapan tresna kuwi kaya criping tela, isa ajur yen ora ngati-ngati le nggawa juga bermakna cinta yang tidak dikelola dengan baik, juga akan menumbuhkan perilaku yang tidak pantas seperti menyiksa diri sendiri, mengganggu rumah tangga orang lain, atau sebaliknya berselingkuh atau mengkhianati pasangan.

\section{b. Datan serik lamun ketaman, datan susah lamun kelangan}

571 | Jurnal Kredo

Vol. 4 No. 22021
Arti ungkapan tersebut adalah jangan gampang sakit hati manakala musibah menimpa diri, jangan terlalu susah manakala kehilangan sesuatu (Mustikarini, 2013). Sementara Kesuma (2013) mengartikan ungkapan tersebut yaitu jangan sakit hati kala musibah datang, jangan mudah menyerah bila menemui kegagalan, jangan sedih kala kehilangan, dan tetap bersyukur atas kenikmatan yang diberikan Tuhan.

Dalam novel Canting, ungkapan ini terdapat dalam kutipan berikut:

\section{Datan serik lamun ketaman}

Datan susah lamun kelangan

Jangan mudah sakit hati saat musibah datang menghampiri

Jangan terus meletakkan kesedihan di hatimu saat kehilangan sesuatu

(Hamida, 2020, hal. 183)

Ungkapan ini digunakan oleh Hamida untuk menggambarkan kondisi Ajeng yang merasa patah hati dan hancur karena kehilangan Hadi. Haryo menasihati Ajeng dengan cara memberitahukan kisahnya agar Ajeng dapat mengambil pelajaran.

"Tapi seiring berjalannya waktu, aku dan Kinanthi bisa saling menerima dan meski berat pada awalnya. Sedangkan Laksita, dia juga dengan legawa menerimanya. Dia berusaha bangkit dan menata hidupnya, bukan malah menghancurkan diri dengan 


Kredo 4 (2021)
KREDO: Jurnal Ilmiah Bahasa dan Sastra
Terakreditasi Sinta 4 berdasarkan Keputusan Direktorat
Jenderal Penguatan Riset dan Pengembangan,
Kementerian Riset, Teknologi dan Pendidikan Tinggi
Republik Indonesia
Nomor: 23/E/KPT/2019. 08 Agustus 2019
https://jurnal.umk.ac.id/index.php/kredo/index

terus mengejarku. Lihatlah Laksita sekarang. Dia berhasil mengukir kebahagiaannya meski tidak bersamaku. Belajar darinya, Jeng." Haryo menutup penjelasannya.. (Hamida, 2020, hal. 192)

Dari kutipan tersebut diketahui bahwa Haryo menasihati Ajeng agar bersikap legawa dan narima. Haryo berharap agar Ajeng bangkit, menata hidupnya kembali, dan menciptakan kebahagiaannya sendiri. Sebagaimana diketahui bahwa rumah tangga adalah realita kehidupan yang komplek. Ungkapan ini mengingatkan setiap orang agar tidak mudah mengeluh, terutama saat tertimpa musibah ataupun kehilangan sesuatu. Justru kita harus bersikap sabar, ikhlas, legawa, dan narima.

Ungkapan ini juga mengingatkan kita agar tidak terpuruk dalam kesedihan berlarut-larut. Justru kita harus bangkit, semangat menata hidup, dan memperjuangkan kebahagiaan kita kembali. Dengan pemahaman ini, kita tidak mudah dipermainkan oleh apapun dan siapapun yang menguji keutuhan rumah tangga kita. Darmoko (2018) mengatakan bahwa ajaran budi pekerti di balik nasihat ini berorientasi pada sifat, sikap, dan tindakan yang bermuara pada nrima, rila, dan sabar.

Manusia sedemikian tergembleng batin dan rohaninya untuk menjaga diri tetap tenang, hening, dan suci dengan upaya pendekatan diri kepada Tuhan. Upaya pendekatan pada Tuhan ini tidak hanya dilakukan sekali saja namun perlu berulang kali dan cenderung terusmenerus agar kualitas diri manusia semakin meningkat dan memiliki derajad keutamaan di hadapan Tuhan Yang Maha Kuasa.

\section{c. Mimi lan mintuna}

Aziz (2017) mengatakan bahwa Mimi lan Mintuna adalah binatang yang tidak pernah berpisah satu sama lain. Karena sifatnya melekat dan tidak pernah berpisah, binatang tersebut dijadikan lambang bagi suami istri untuk selalu bersatu padu secara lahir batin agar keduanya dapat hidup tenang, tenteram, dan selamat.

Dari pengertian tersebut, pasangan suami istri laksana mimi lan mintuna berarti setiap pasangan dalam menjalani kehidupan berumah tangga senantiasa menerapkan asas setel kendho terhadap setiap kehendak diri dan pasangan agar senantiasa serasi, rukun, tenteram, bahagia.

Dalam novel Canting ungkapan mimi lan mintuna terdapat dalam kutipan berikut.

Iya, Mas. Saat menikah, banyak yang berpesan begitu. Dadia kaya Mimi lan Mintuna, jadilah seperti Mimi dan Mintuna. Tapi aku belum tahu mereka apa. Yang aku tahu, mereka adalah simbol kesetiaan. “jawab Sekar. (Hamida, 2020, hal. 101) 


Kredo 4 (2021)
KREDO: Jurnal Ilmiah Bahasa dan Sastra
Terakreditasi Sinta 4 berdasarkan Keputusan Direktorat
Jenderal Penguatan Riset dan Pengembangan,
Kementerian Riset, Teknologi dan Pendidikan Tinggi
Republik Indonesia
Nomor: 23/E/KPT/2019. 08 Agustus 2019
https://jurnal.umk.ac.id/index.php/kredo/index

“... Tapi aku pernah membaca, Mimi dan Mintuna ini adalah sejenis hewan di perairan dangkal di kawasan Mangrove. Sekilas bentuknya seperti serangga, tetapi memiliki cangkang seperti kepiting. Mimi sebutan bagi yang jantan, Mintuna sebutan bagi yang betina. Dijadikan simbol kesetiaan, karena hewan ini termasuk monogamik, hanya setia pada satu pasangan. Tidak berganti-ganti. Kabarnya jika dipisahkan dari satu pasangannya, maka hewan ini akan mati. Tapi aku belum menemukan penjelasan ilmiah soal yang ini. Yang pasti, aku ingin kita seperti mereka. Terus bersama hingga maut memisahkan kita," jelas Hadi panjang lebar, sambil terus memberikan tatapan hangat pada Sekar (Hamida, 2020, hal. 102).

Dari kutipan tersebut diketahui bahwa ungkapan mimi lan mintuna memiliki makna setiap pasangan hendaknya saling setia sehingga rumah tangganya langgeng dan bahagia.

\section{d. Urip rekasa gelem, mukti uga bisa, sabaya mukti, sabaya pati}

Artinya hidup sengsara mau, bahagia juga bisa, sehidup semati dalam suka maupun duka. Menurut Afidah (2020) makna ungkapan tersebut adalah hidup dalam kesusahan bersedia, hidup makmur pun bisa, sehidup semati dalam suka maupun duka. Dari pengertian tersebut, ungkapan urip rekasa gelem, mukti uga bisa, sabaya mukti, sabaya pati berarti sebuah pernikahan, pasangan suami istri hendaknya saling setia, tidak hanya dalam keadaan bahagia, tetapi juga dalam keadaan kesusahan. Setia memiliki arti berpegang teguh (pada janji, pendirian, dan sebagainya), patuh, taat, tetap, dan teguh hati.

Inilah nilai yang mesti dipegang teguh oleh setiap pasangan dalam berumah tangga. Ia menganggap pasangan bukan semata-mata menjadi teman hidup ketika hidup di dunia, tetapi juga di akhirat kelak. Dalam novel Canting, ungkapan tersebut terdapar dalam kutipan berikut.

"Dengarkan aku, Mas. Urip rekasa gelem, mukti uga bisa, sabaya mukti, sabaya mukti. Hidup dalam kesusahan bersedia, hidup makmur pun bisa, sehidup semati dalam suka maupun duka. Itulah aku padamu, Mas," katanya. Kini giliran Hadi yang terkesiap setelah mendengar istrinya (Hamida, 2020, hal. 208).

Dari kutipan tersebut diketahui bahwa Sekar menyatakan kesetiaannya pada Hadi. Sekar dengan ikhlas terus merawat dan membuktikan baktinya pada Hadi. Sekar senantiasa membersamai Hadi, tidak hanya dalam keadaan makmur dan bahagia, tetapi juga bersedia bersamanya dalam kesusahan. Dengan demikian, dalam konteks rumah tangga, makna ungkapan 


Kredo 4 (2021)
KREDO: Jurnal Ilmiah Bahasa dan Sastra
Terakreditasi Sinta 4 berdasarkan Keputusan Direktorat
Jenderal Penguatan Riset dan Pengembangan,
Kementerian Riset, Teknologi dan Pendidikan Tinggi
Republik Indonesia
Nomor: 23/E/KPT/2019. 08 Agustus 2019
https://jurnal.umk.ac.id/index.php/kredo/index

urip rekasa gelem, mukti uga bisa, sabaya mukti, sabaya mukti adalah pasangan suami istri hendaknya saling setia dalam keadaan apapun, baik dalam keadaan suka maupun duka.

\section{SIMPULAN}

Dari hasil penelitian yang telah dilakukan terhadap novel Canting karya Fissilmi Hamida dapat disimpulkan bahwa dalam novel Canting karya Fissilmi Hamida terdapat nilai-nilai budaya Jawa yang terkandung dalam ungkapan-ungkapan Jawa yang berlatar rumah tangga. Ada lima nilai budaya Jawa yang ditemukan dalam penelitian ini yaitu nilai keyakinan, nilai kesabaran, nilai pengharapan dan pencapaian, nilai keselarasan, dan nilai kesetiaan.

Nilai keyakinan (keteguhan) ungkapan gegaraning wong akrami, dudu banda, dudu rupa, amung ati pawitane, ungkapan Gusti paring dalan kanggo wong sing ngelam dalan dan ungkapan Gusti paring pitedah, bisa lewat bungah, bisa lewat susah. Nilai kesabaran terdapat dalam ungkapan wani ngalah luhur wekasane, ungkapan aja obah yen atimu kemrayah, aluwung meneng nganti atimu lerem dan ungkapan suradira jayaningrat lebur dening pangastuti.

Nilai pencapaian (harapan) terdapat dalam ungkapan gulo, gulangane roso, ungkapan udhek tegese usahane aja nganti mandhek, ungkapan sendhok, sendhekno marang sing kuasa, ungkapan adem, ati digawa lerem dan ungkapan seruput, sedaya rubeda bakal luput.

Nilai keselarasan terdapat dalam ungkapan tresna kuwi kaya criping tela, isa ajur yen ora ngati-ngati le nggawa, ungkapan datan serik lamun ketaman, datan susah lamun kelangan. Ungkapan mimi lan mintuna dan ungkapan urip rekasa gelem, mukti uga bisa, sabaya mukti, sabaya pati.

Nilai-nilai budaya Jawa yang terkandung dalam ungkapan Jawa berlatar rumah tangga dalam novel Canting karya Fissilmi Hamida dapat dijadikan sebagai pedoman bagi pasangan suami istri dalam mengupayakan keharmonisan rumah tangga.

\section{DAFTAR PUSTAKA}

Afidah, A. N., Mulyono, T., \& Nirmala, A. A. 2020. Citra Perempuan Jawa Dalam Novel Garis Perempuan karya Sanie B. Kuncoro Dan Implikasinya Terhadap Pembelajaran Bahasa Indonesia Di SMA. Jurnal Wahana Pendidikan, 7(2), 151164. https://doi.org/10.25157/wa.v7i2.3588 


Kredo 4 (2021)
KREDO: Jurnal Ilmiah Bahasa dan Sastra
Terakreditasi Sinta 4 berdasarkan Keputusan Direktorat
Jenderal Penguatan Riset dan Pengembangan,
Kementerian Riset, Teknologi dan Pendidikan Tinggi
Republik Indonesia
Nomor: 23/E/KPT/2019. 08 Agustus 2019
https://jurnal.umk.ac.id/index.php/kredo/index

Ajrin, S. 2017. Kebahagiaan Perkawinan Isteri dalam Konsep Perempuan Ideal Jawa. Kafa `ah: Journal of Gender Studies, 7(1), 26-41. https://doi.org/10.15548/jk.v7i1.167

Aziz, S. 2017. Tradisi Pernikahan Adat Jawa Keraton Membentuk Keluarga Sakinah. IBDA: Jurnal Kajian Islam dan Budaya, 15(1), 22-41. https://doi.org/10.24090/ibda.v15i1.724

Bakry, S. N. 1996. Kunci Keutuhan Rumah-Tangga (Keluarga yang Sakinah) (2 ed.). Pedoman Ilmu Jaya.

Damono, S. D. 1978. Sosiologi Sastra: Sebuah Pengantar Ringkas. Pusat Pembinaan dan Pengembangan Bahasa Departemen Pendidikan dan Kebudayaan. http://repositori.kemdikbud.go.id/2385/1/Sosiologi Sastra Sebuah Pengantar Ringkas \%281978\%29.pdf

Darmoko. 2018. Bahasa Dan Sastra Di Era Multimedia: Sebuah Metode Analisis Ungkapan Kata-Kata Mutiara Jawa Dalam Media Digital. Seminar Nasional 2018 : Inovasi Ipteks untuk Peningkatan Daya Saing Sumber Daya Manusia, 137-146. http://prosiding.univetbantara.ac.id/index.php/SN2018/article/view/22/16

De Jong, D. S. 1976. Salah Satu Sikap Hidup Orang Jawa. Kanisius.

Departemen Kebudayaan dan Pariwisata. 2007. Himpunan Pitutur Luhur (2 ed.). Direktorat Kepercayaan terhadap Tuhan Yang Maha Esa.

Endraswara, S. 2012. Metodologi Penelitian Sastra. CAPS Publishing.

Firmansyah, E. 2013. Refleksi Budaya Jawa Dalam Novel Bumi Manusia dan Anak Semua Bangsa Karya Pramoedya Ananta Toer : Persfektif Filsafat. Literasi : Jurnal Ilmu-Ilmu Humaniora, $3(2)$, 144-149. https://jurnal.unej.ac.id/index.php/LIT/article/view/6124

Hamida, F. 2020. Canting. KMO Publishing.

Jazeri, M. 2020. Makna Tata Simbol Dalam Upacara Pengantin Adat Jawa (K. H. T. $\begin{array}{lllll}\text { Sunarto } & \text { (ed.); } & 1 & \text { ed.). } & \text { Akademia }\end{array}$

575 | Jurnal Kredo Vol. 4 No. 22021 


Kredo 4 (2021)
KREDO: Jurnal Ilmiah Bahasa dan Sastra
Terakreditasi Sinta 4 berdasarkan Keputusan Direktorat
Jenderal Penguatan Riset dan Pengembangan,
Kementerian Riset, Teknologi dan Pendidikan Tinggi
Republik Indonesia
Nomor: 23/E/KPT/2019. 08 Agustus 2019
https://jurnal.umk.ac.id/index.php/kredo/index

Kemendikbud. (n.d.). KBBI Kemendikbud. https://kbbi.kemdikbud.go.id/

Kesuma, D., Triatna, C., \& Permana, H. J. (2013). Pendidikan Karakter Kajian Teori Dan Praktik Di Sekolah (1 ed.). Remaja Rosdakarya.

Koentjaraningrat. 1984. Kebudayaan Jawa. Balai Pustaka.

Mulyani, S. 2019. The Principle Obedience to the Pragmatic Aspects in Javanese Humor Memes (An Effort to Explore Javanese Local Wisdom). INCOLWIS : International Conference on Local Wisdom. https://doi.org/10.4108/eai.29-8-2019.2289008

Mustikarini, I. D. 2013. Budaya Jawa Sebagai Wahana Pendidikan Moral Anak. Citizenship: Jurnal Pancasila dan Kewarganegaraan, 2(1). https://doi.org/10.25273/citizenship.v2i1.3429

Mustofa, I. 2008. Keluarga Sakinah dan Tantangan Globalisasi. Al-Mawarid, 18, 227248. https://doi.org/10.20885/almawarid.vol18.art5

Oktaviani, M. I. 2010. Nilai-Nilai Budaya Jawa Dalam Ungkapan- Ungkapan Jawa Yang Berlatar Perkawinan [Universitas Indonesia]. http://lib.ui.ac.id/file?file=digital/20160911-RB02M45n-Niliai-nilai bydaya.pdf

Pikatan, I. 2012. Ajaran Berumah Tangga dalam Serat Candrarini Karya Ranggawarsita (Tinjauan Sosiologi Sastra). Penelitian Humaniora, 13(1), 42-48. https://doi.org/10.23917/humaniora.v13i1.913

Pitoyo, D. 2009. Ajaran Moral Berumah Tangga Dalam Serat Darmawasita Karya K.G.P.A.A. Mangkunagoro IV. Jurnal Filsafat, 19(3), 215-233. https://doi.org/10.22146/jf.3436

Puspitasari, D. 2016. Kajian Sosial Budaya Dalam Serat Candrarini Pada Masa Paku Buwono IX (1861-1893). Candi : Jurnal Penelitian dan Pendidikan Sejarah, 13(1), 53-71. https://jurnal.uns.ac.id/candi/article/view/42815/27585 


Kredo 4 (2021)
KREDO: Jurnal Ilmiah Bahasa dan Sastra
Terakreditasi Sinta 4 berdasarkan Keputusan Direktorat
Jenderal Penguatan Riset dan Pengembangan,
Kementerian Riset, Teknologi dan Pendidikan Tinggi
Republik Indonesia
Nomor: 23/E/KPT/2019. 08 Agustus 2019
https://jurnal.umk.ac.id/index.php/kredo/index

Rachim, R. L., \& Nashori, H. F. 2007. Nilai Budaya Jawa dan Perilaku Nakal Remaja Jawa. Indigenous: Jurnal Ilmiah Psikologi, 09(1), 30-43. https://doi.org/10.23917/indigenous.v9i1.1653

Rafiatun, N. 2018 Nilai Pendidikan Islam dalam Kesenian Tembang Macapat. Millah : Jurnal Studi Agama, 17(2), 379-400. https://doi.org/10.20885/millah.vol17.iss2.art9

Ratna, N. K. 2011. Teori, Metode, Dan teknik Penelitian Sastra. Pustaka Pelajar.

Saiin, A. 2018. Efektivitas Kafā'ah Membentuk Rumah Tangga Harmonis Perspektif Undang-Undang No. 1 Tahun 1974. Equitable, 3(1), 12-28. https://doi.org/10.37859/jeq.v3i1.807

Sari, I. D. 2016. Pemanfaatan Stiker Untuk Media Pembelajaran Gaya Bahasa Eufemisme Di Kelas XI MAM 1 Sragen [Universitas Muhammadiyah Surakarta]. http://eprints.ums.ac.id/45260/24/NASKAH PUBLIKASI.pdf

Sundari, W. 2008. Ungkapan Dalam Upacara Tradisional Perkawinan Suku Jawa. Kajian Sastra: Jurnal Bidang Kebahasaan dan Kesusastraan, 32(1), 71-80. https://ejournal.undip.ac.id/index.php/kajiansastra/article/view/2951/2637

Swingewood, A., \& Laurenson, D. 1972. The Sociology of Literature. Granada Publishing.

Taylor, S. J., Bogdan, R., \& DeVault, M. L. 2016. Introduction to Qualitative Research Methods : A Guidebook and Resource (4th ed.). John Wiley \& Sons.

Wahjono, P. 2004. Sastra Wulang Dari Abad XIX: Serat Candrarini Suatu Kajian Budaya. MAKARA of Social Sciences and Humanities Series, 8(2), 71-82. http://journal.ui.ac.id/index.php/humanities/article/view/91

Wahyudi, T. 2013. Sosiologi Sastra Alan Swingewood Sebuah Teori. Jurnal Poetika, 1(1). https://jurnal.ugm.ac.id/poetika/article/view/10384/7839 


\begin{tabular}{|c|c|c|} 
Kredo 4 (2021) \\
KREDO: Jurnal Ilmiah Bahasa dan Sastra \\
Terakreditasi Sinta 4 berdasarkan Keputusan Direktorat \\
Jenderal Penguatan Riset dan Pengembangan, \\
Kementerian Riset, Teknologi dan Pendidikan Tinggi \\
Republik Indonesia \\
Nomor: 23/E/KPT/2019. 08 Agustus 2019 \\
https://jurnal.umk.ac.id/index.php/kredo/index
\end{tabular}

Wibisono, Y. 2020. Falsafah Bangsa Dan Budaya Jawa Dalam Pemikiran Soeharto. Jurnal Ilmu dan Budaya, 41(68), 7979-7988. http://journal.unas.ac.id/ilmubudaya/article/view/874/718 